\title{
Erratum to: 10th Central European Congress of Rheumatology CECR 2014, Abstract 04.02
}

A. Siwiec

Published online: 30 June 2016

(C) Springer-Verlag Wien 2016

\section{Erratum to:}

Wien Klin Wochenschr (2014) 126 (Suppl 5): S199-S234

DOI $10.1007 / \mathrm{s} 00508-014-0671-9$

The following funding information was omitted from Abstract O4.02 on page S204: "Acknowledgment: This work was funded by The Polish National Science Center, based on the decision PRO-2011/01/N/NZ5/00289."

Conflict of interest A. Siwiec states that there are no conflicts of interest. 